\title{
THE DISCOVERY OF THE MITHRAS STATUE OF TARQUINIA
}

Summary: In 2014 the discovery of a Mithras' statue at Tarquinia occurred. This was due to the Comando Tutela Patrimonio Culturale dell'Arma dei Carabinieri, which informed the Soprintendenza per i Beni Archeologici dell'Etruria Meridionale about clandestine activities in May 2014 on the poggio della Civita - where the ancient city of Tarquinia stood - in a zone close to the Etruscan temple of the Ara della Regina (fig. 1).

As soon as possible, the Soprintendenza carried out an archaeological excavation, focusing the effort on the need to find evidence for the place of origin of the magnificent sculptural group (fig. 2), which represents Mithras Tauroctonus. This sculpture was recovered by the Carabinieri after investigation by the police, directed by the Procura della Repubblica of the law court of Rome.

Archaeological research since then has led to the discovery of another marble part of the same sculpture (fig. 3), i.e., the dog leaning on the knee of the bull and perfectly dovetailing with the Mithraic Tauroctony. The discovery of another fragment pertaining to the same sculpture is an irrefutable proof that the Mithras' statue came from the domus of the Civita of Tarquinia, which represents an important and new scientific result.

The only other sculptural group depicting Mithras in Southern Etruria was one previously found in Vulci, discovered in 1975 after a clandestine excavation close to the domus del Criptoportico. This new finding proves the spread of this cult in Tarquinia, as well, and the style of the new sculpture suggests a chronological priority of the Tarquinian Mithraeum in respect to that in Vulci.

Key words: Mithras, Tarquinia, Civita

In May 2014, clandestine activities were reported to the Comando Tutela Patrimonio Culturale dell'Arma dei Carabinieri, which informed the Soprintendenza per i Beni Archeologici dell'Etruria Meridionale. ${ }^{1}$ An investigation led to the discovery of a Mithras'

${ }^{1}$ I am grateful to the Soprintendente Alfonsina Russo for having supported this intervention and providing it with funds, and for her precious advice. I thank the Carabinieri of the Department for the protection of the Cultural Heritage, without whose intervention the Tarquinian statue would have been taken abroad. Many thanks to the assistant Tortolini, who speaks little but has been a very efficient participant in this work, about which the police recommended discretion. I thank also the archaeological 


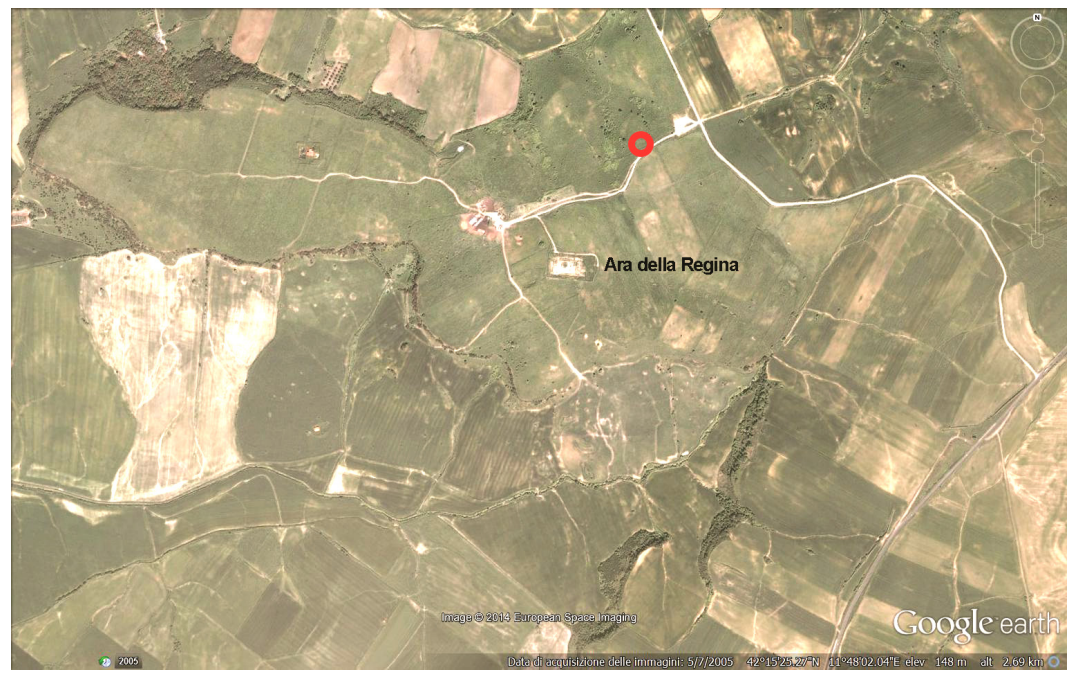

Fig. 1. Tarquinia. loc. "Civita" - positioning of the Mithras domus (drawn by the archaeological firm Legni e Segni della Memoria)

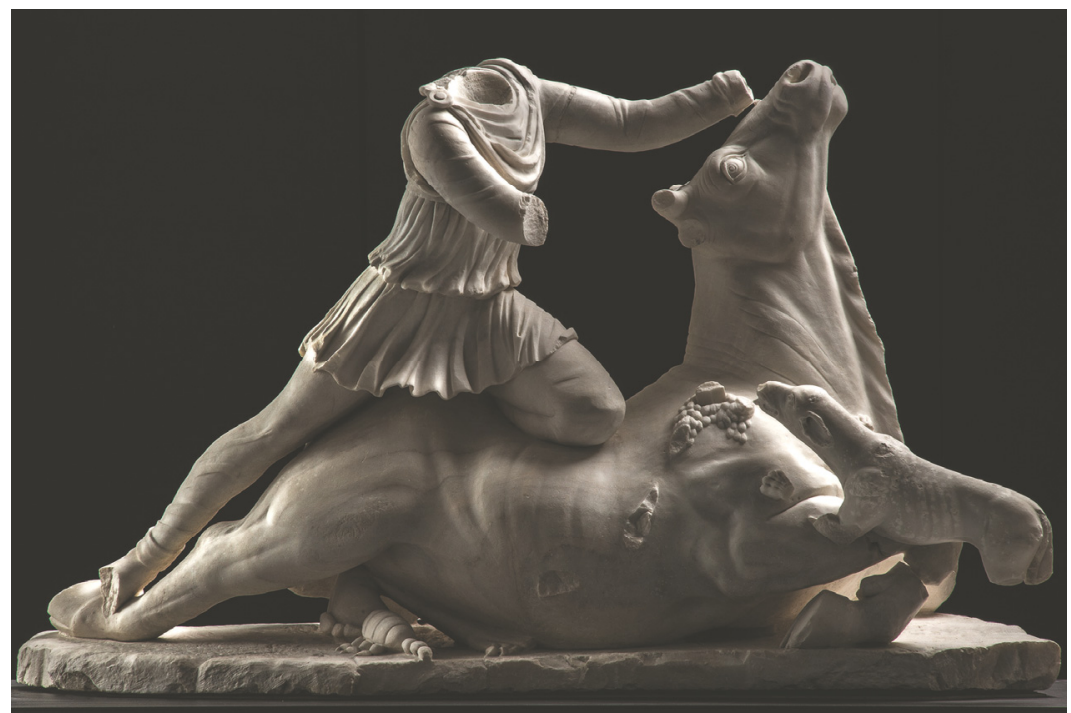

Fig. 2. Mithras Tauroctonus from the "Civita" in Tarquinia (photo by M. Benedetti)

firm Legni e Segni della Memoria, from Salerno, run by Giovanni Gallo, which carried out the excavation without divulging it, and I thank particularly Salvatore Ciro Nappo and Gennaro Iovino whose concern has been that of documenting and drawing the excavation. Subsequently, the designer L. Petolicchio worked further on the documentation for the publication. I am particularly grateful to the Fondazione Etruria Mater which, thanks to fundings from the ENEL s.p.a., carried out the featuring of the museum room for the statue in Tarquinia. I am grateful to Attilio Mastrocinque for having translated my Italian text into English. 


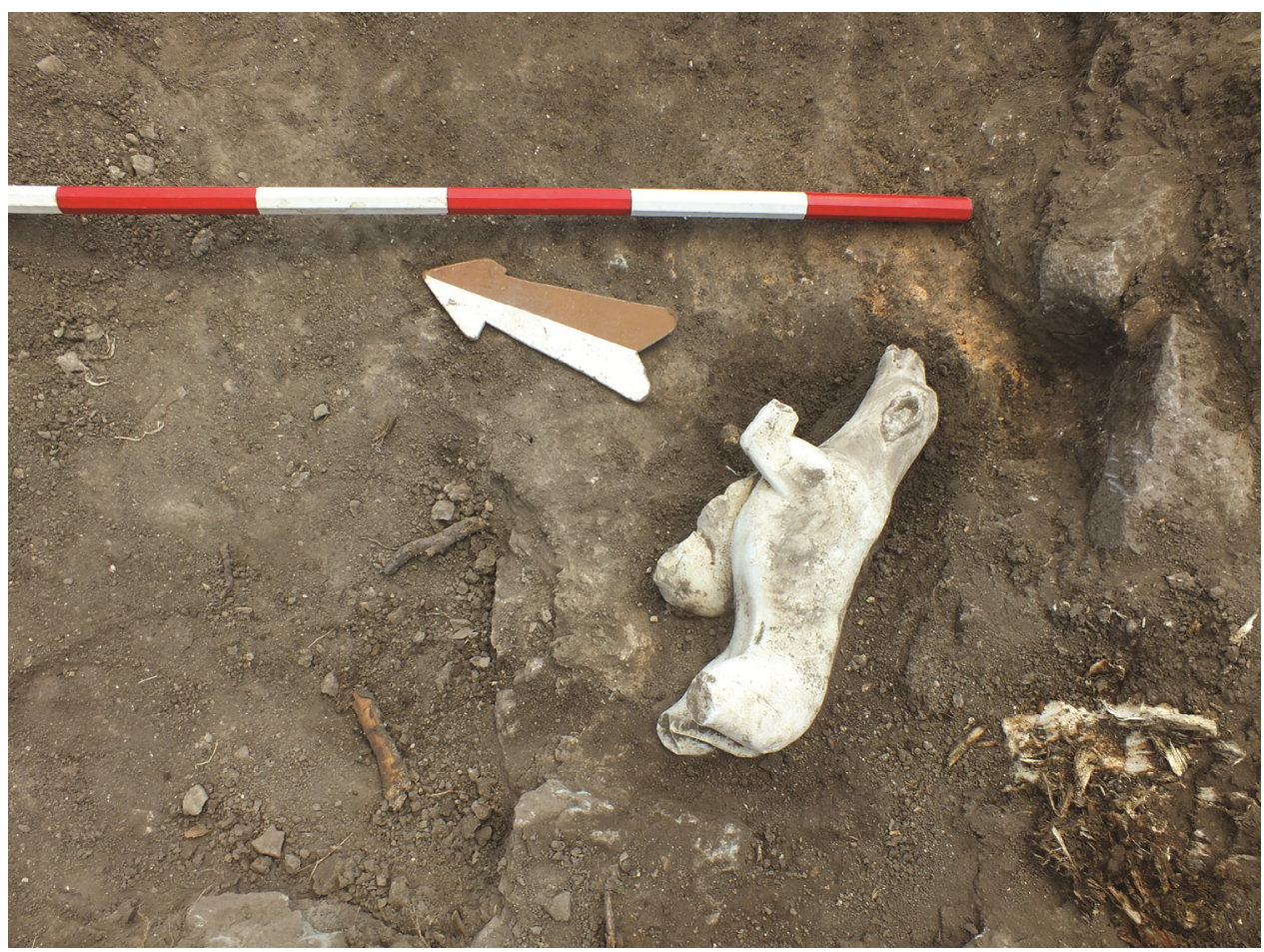

Fig. 3. Fragment of the sculptural group pertinent to the dog at the time of the discovery (photo by the archaeological firm Legni e Segni della Memoria)

statue there, on the poggio della Civita - where the ancient city of Tarquinia stood in a zone close to the Etruscan temple of the Ara della Regina (fig. 1).

As soon as possible, the Soprintendenza per i Beni Archeologici dell'Etruria Meridionale carried out an archaeological excavation, focusing the effort on the need to find evidence for the place of origin of the magnificent sculptural group (fig. 2), which represents Mithras Tauroctonus. This sculpture was recovered by the Carabinieri after investigation by the police, directed by the Procura della Repubblica of the law court of Rome.

\section{THE MITHRAS OF TARQUINIA}

White imported marble. Dimensions: height from the base to the neck of Mithras: $\mathrm{cm} 89$, height to the head of the bull: $\mathrm{cm} 90.5$, maximal length $\mathrm{cm} \mathrm{154,} \mathrm{maximal} \mathrm{width} \mathrm{of} \mathrm{the}$ base: $\mathrm{cm} \mathrm{43:} \mathrm{thickness} \mathrm{of} \mathrm{the} \mathrm{base:} \mathrm{cm} 7$.

The sculpture of the Mithras of Tarquinia (figs 4-5) is missing some of the inserted parts, i.e., the head, the left hand, the left foot of the god, and the left ear of the bull, 


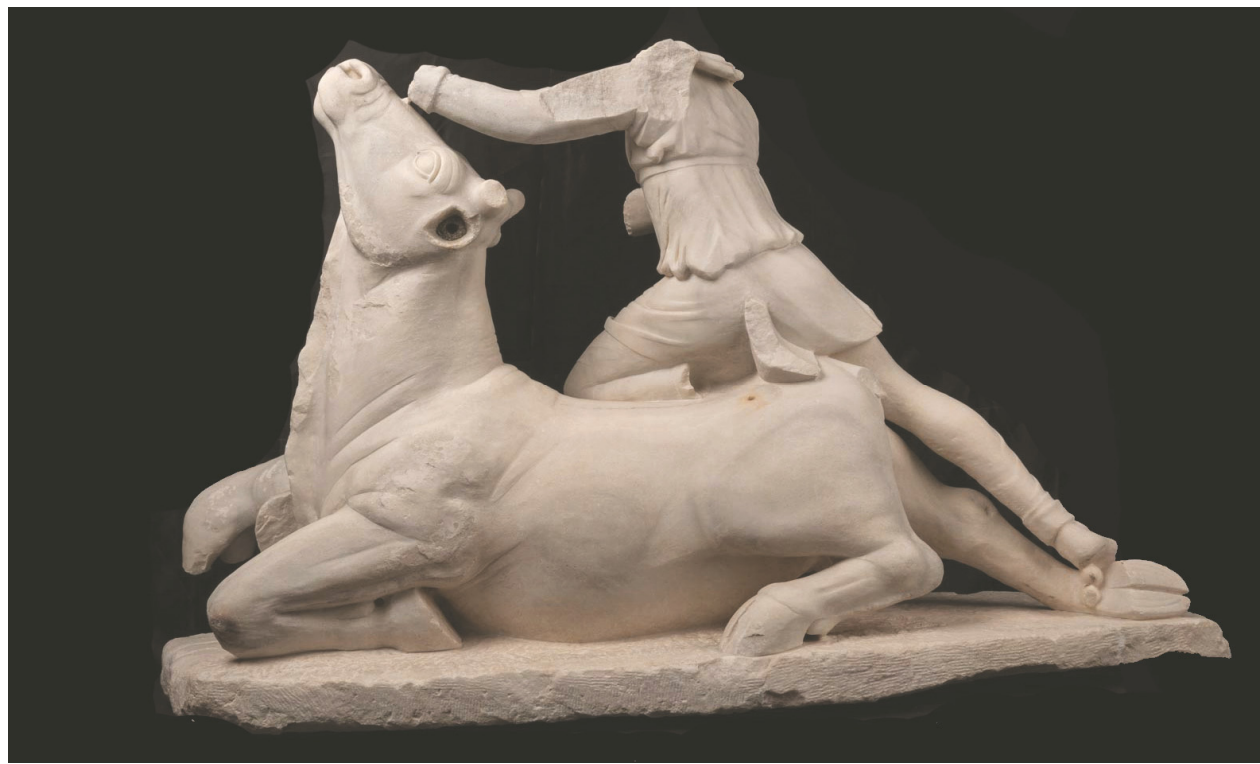

Fig. 4. Mithras Tauroctonus from the "Civita" in Tarquinia. Back (photo by M. Benedetti)

on which are traces of the ancient plumbing by a gudgeon ${ }^{2}$ for fixing the inserted pieces. The Istituto Superiore per la Conservazione ed il Restauro ${ }^{3}$ carried out a careful cleaning and removed the earth and limestone incrustations from the marble surface. The left arm, subsequently handed over to the Carabinieri, as well as the dog, were added to the sculpture after the digging by the Soprintendenza. ${ }^{4}$

More recent investigation by the Carabinieri has allowed the recovery of other marble fragments (fig. 6), which fit the sculptural group perfectly and will contribute to its completeness when they will have been attached. They consist of a part of the base with a trace of the dog's paw, parts of the snake, part of the right hand of Mithras holding the dagger, part of Mithras mantle, and part of the bull's tail, whose end is shaped as an ear's bunch. The hilt is decorated with a big precious stone, similar to that on the fibula on the right shoulder of the god.

The attitude of this Mithras is canonical for all his cultic statues, and derives from a Pergamene prototype which can be found everywhere in the Roman Empire, as is especially proved by sculptures, reliefs, and three paintings (in Rome: Mithraeum Barberini, Santa Maria Capua Vetere, and Marino).

Mithras wears a short tunic with two flounces and long sleeves (tunica manicata), a belt on the chest, long oriental-style trousers (anaxyrides), and is barefoot.

\footnotetext{
${ }^{2}$ A gudgeon is a socket-like, cylindrical fitting attached to one component to enable a pivoting or hinging connection to a second component. https://en.wikipedia.org/wiki/Gudgeon

${ }^{3}$ The restoration was directed by M. C. Laurenti and made by L. Festa and F. Vischetti.

${ }^{4}$ The firm EQUILIBRARTE proceeded to assemble the dog and the left arm to the sculptural group through pins.
} 


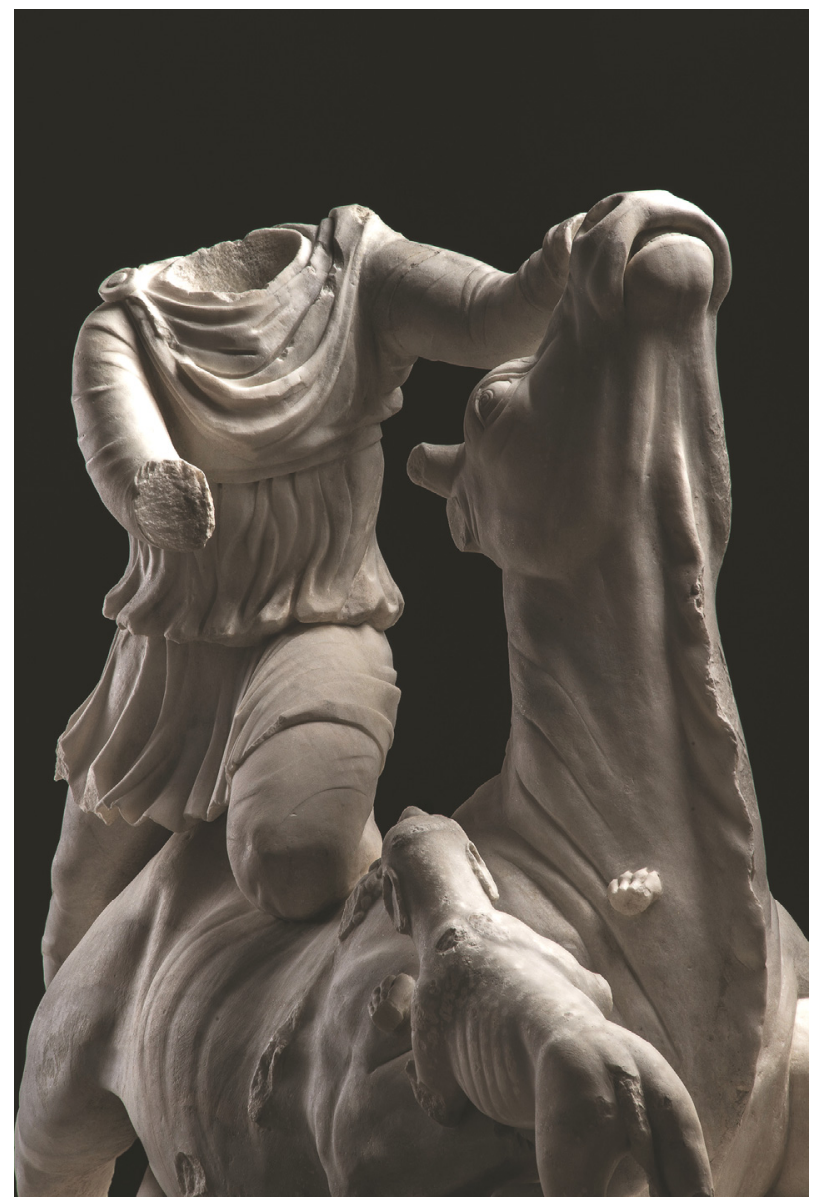

Fig. 5. Mithras Tauroctonus from the "Civita" in Tarquinia. Detail (photo by M. Benedetti)

His mantle is fastened with a large round fibula decorated with a big precious stone, which is recurrent in Mithras' dress. He is leaning on the back of the bull, with his left leg inflected, whereas his right leg is stretched over the hind right leg of the bull. His torso is bent to the right and going forwards. In spite of the lack of his head, it is possible to hypothesize that it was turned right, following the torsion of the body, as we can infere from many known sculptures whose attitudes are evident from the point of view of the devotees.

The bull seems to exhale its last breath (fig. 7); its mouth is slightly open and its anatomical details are carefully cut: its inferior incisor teeth can be seen on the jaw, whereas it has no upper teeth, like all ruminants. Its right hind hoof is also rich in detail. Mithras forces the bull to bend its neck backwards with his left hand (which is missing), which would be holding its nostrils, whereas his right hand stabs the animal on the neck. Blood drops are gushing forth from the wound, and the dog and the snake are licking them. A scorpion is biting the testicles of the bull with its pincers. 


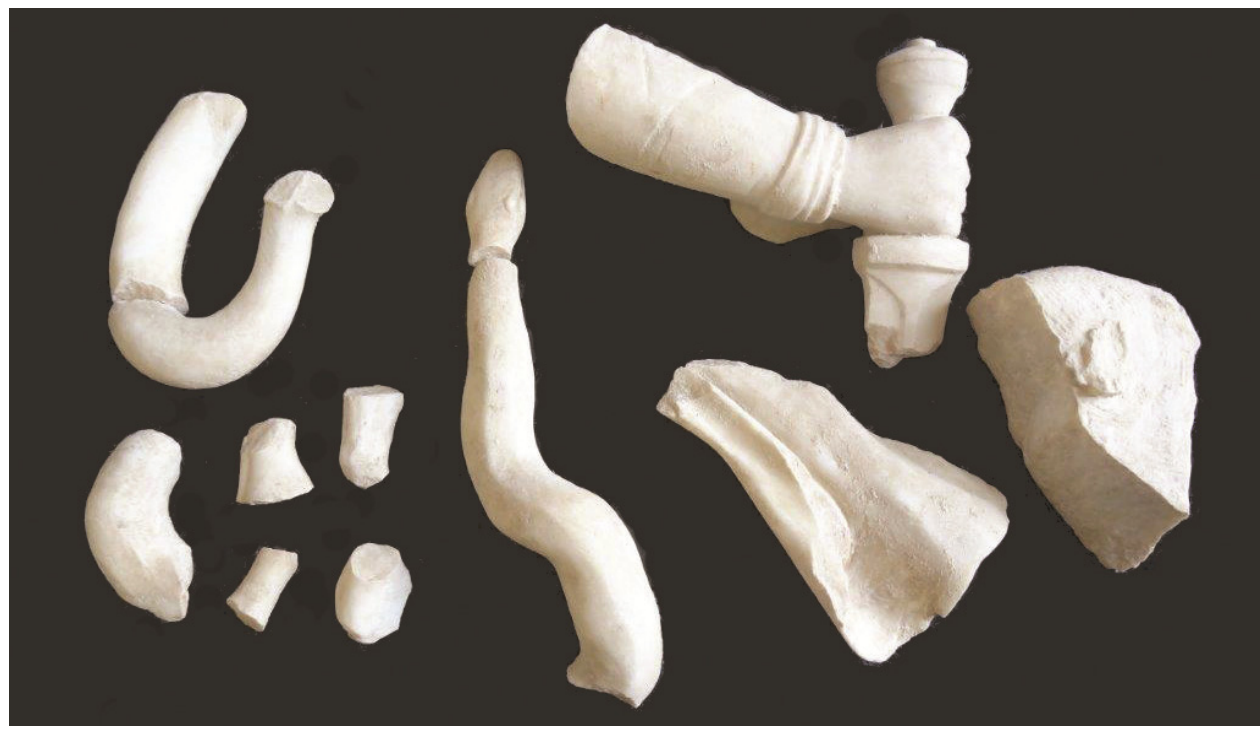

Fig. 6. New fragments of the Mithras recovered by the Carabinieri C.T.P.C. (photo by M. Benedetti)

The pupils of the bull's eyes are represented by means of a spiral; those of the dog are slightly hollow. The inner corner of the bull's eyes have a small hole made with a tiny drill bit to depict the tear duct. We notice traces of the use of a larger drill bit on the hoof of the left foreleg and in some spots of the upper flounce of Mithras' dress, where the folds of his tunic begins from its mid-part. The forepart of the base is cut with incisions, which allude to a rocky zone and to the canonical cave wherein the Tauroctony took place. The hinder part of the base, instead, is less refined and still preserve traces of the work with a toothed hammer. Apart from this one difference between the fore and the hind part of the base, all the rest of the work is perfectly engraved and well-rounded in the front and on the rear.

The quality of the work is absolutely high and it was probably cut by a sculptor in Rome and then brought to Tarquinia. The statue was the work of a cultivated artist, who knew of Hadrianic Classicism and its sculptural production, in whose frame he probably worked, and of the canons of cultic statues of Mithraism. The small details in the tear duct of the bull and the non-extensive use of the drill suggest a chronology within the early years of the emperor Antoninus Pius (138-161 CE).

\section{THE DOMUS OF MITHRAS’ STATUE}

Limited research aimed at focusing on the source of the sculpture, after the intervention of the Carabinieri, has brought to light a complex building perfectly oriented, according to the cardinal points, along a line North-South, and this evidently shows the building project. It was impossible, however, to find either the main gate from the external road or the indoor passages, because the investigated area has been small. 


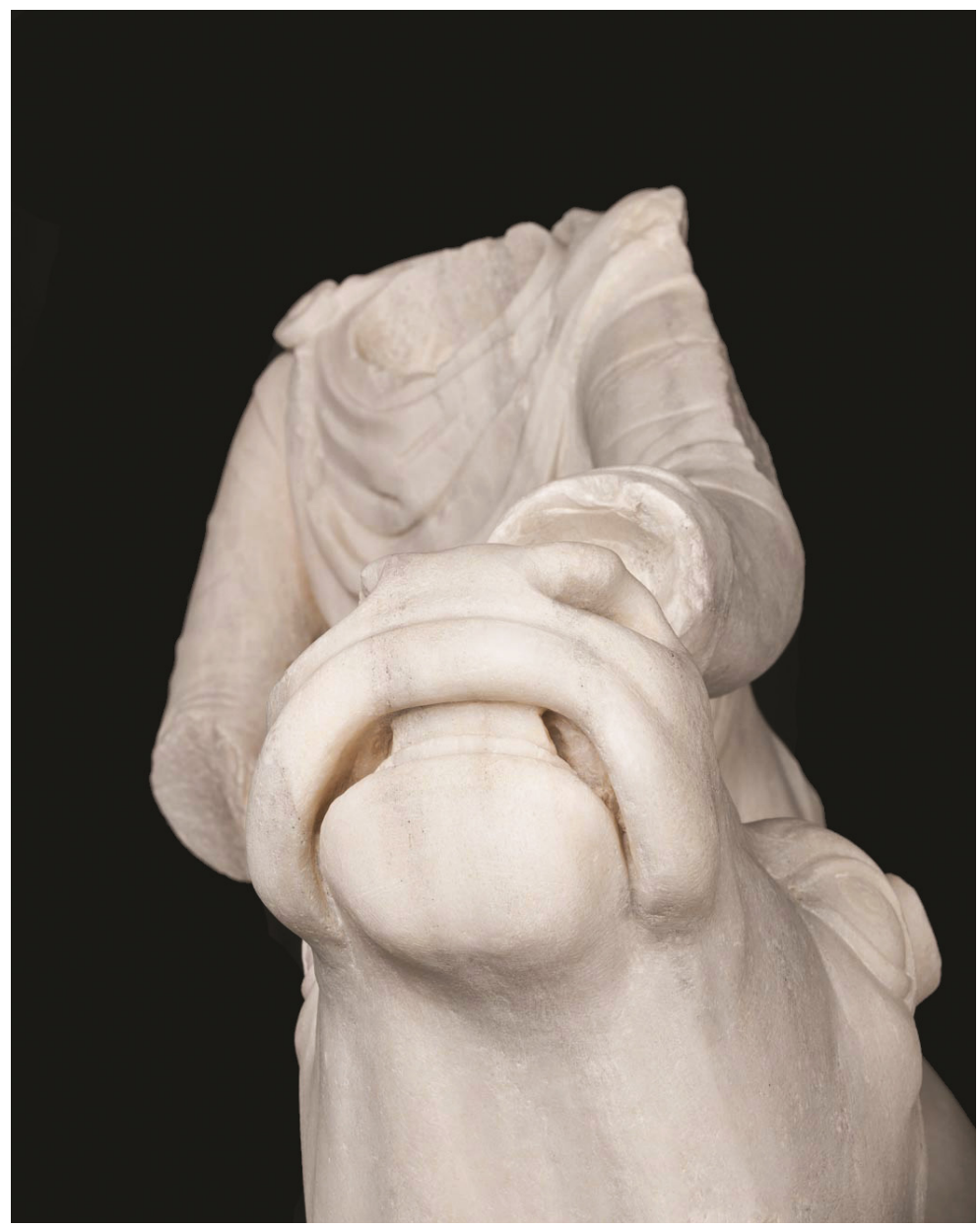

Fig. 7. Detail of the muzzle of the bull of the Mithras statue of Tarquinia (photo by M. Benedetti)

The excavated area (lat. $11^{\circ} 48^{\prime} 10^{\prime \prime}$ North, long. $42^{\circ} 15^{\prime} 38^{\prime \prime}$ East) is abutting the small road on beaten earth which runs East to West on the plateau. The architectural complex stood within the ancient city walls in a zone which is called "Pian della Regina”, because the Etruscan temple known as Ara della Regina is only 300 meters distant from the house of Mithras (fig. 8).

Only a few remains of this house can be seen. The lines of the walls can be appreciated only in the planimetry, and several of them are preserved only with a single row of stone blocks. Damage from ploughing with tractors and roots of the ferulae, typical plants in this zone, had intruded between the stones of the ancient walls and moved the structures from their original emplacement.

The stratigraphy did not produce clarifying results, for there was only a hard, clayish layer rich in various stones and ceramic sherds of different chronologies, ranging from the black vernis (2nd century BCE) to the coarse ware and Terra Sigillata 


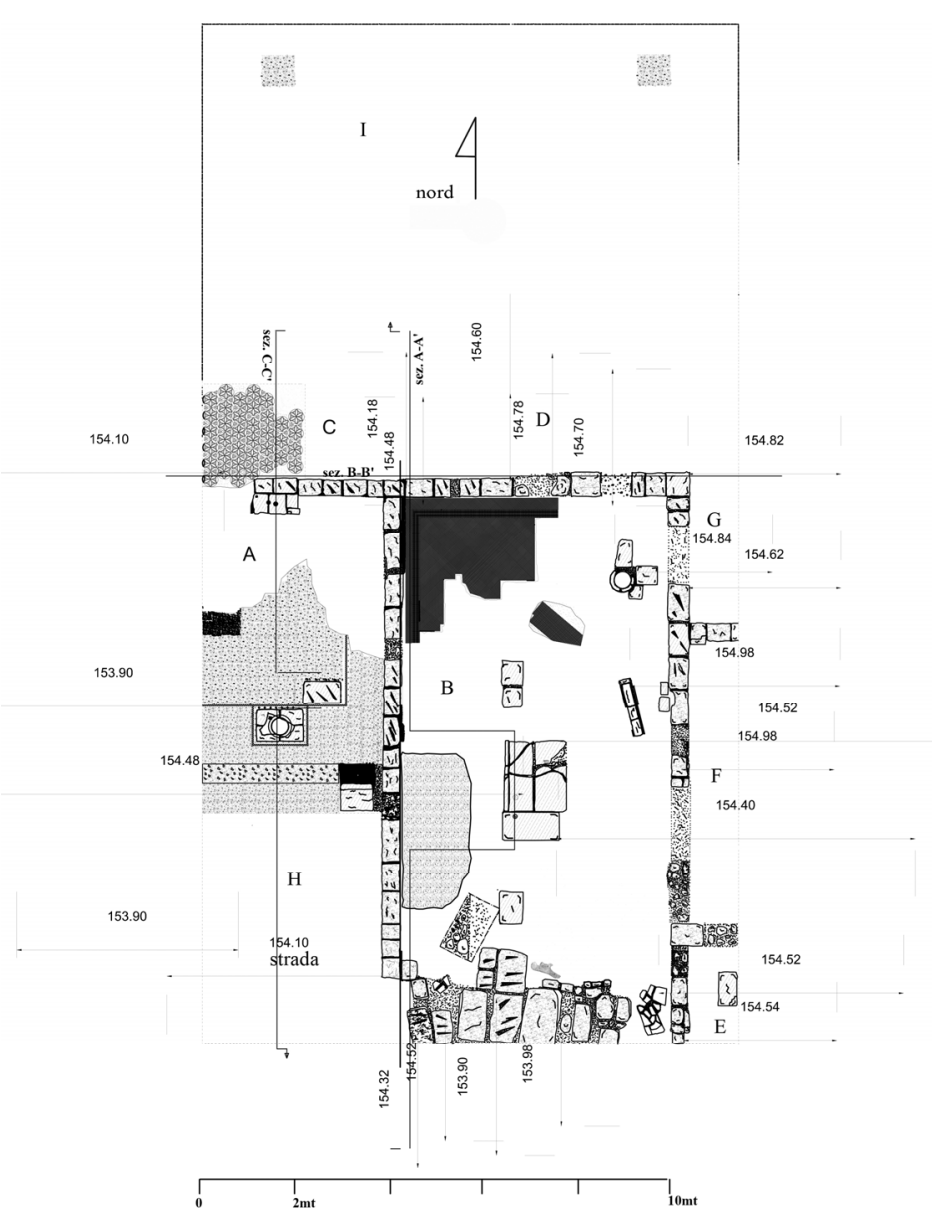

Fig. 8. Tarquinia, loc. "Civita" - general plan of the Domus of Mithras (drawn by the archaeological firm Legni e Segni della Memoria)

(2nd to 5th century CE). The stratigraphy was evidently perturbed, as the sherds lying in upset earth shows.

The room within which the statue has been found is a part of a complex domus, of which nine rooms have been identified, among whom two have been completely dug (A and B), one (C) partially dug, and the fourth one (room H, which had only been recognized).

\section{ROOM A}

Room A (fig. 9) has been partially excavated, and its Western part is still underground. Its Northern part is limited by a wall made of macco stone blocks, whose foundation layer is still preserved, and a threshold, as well, is visible with its hollow for the pivot and the indent for the door, which allowed one to pass towards room C. 


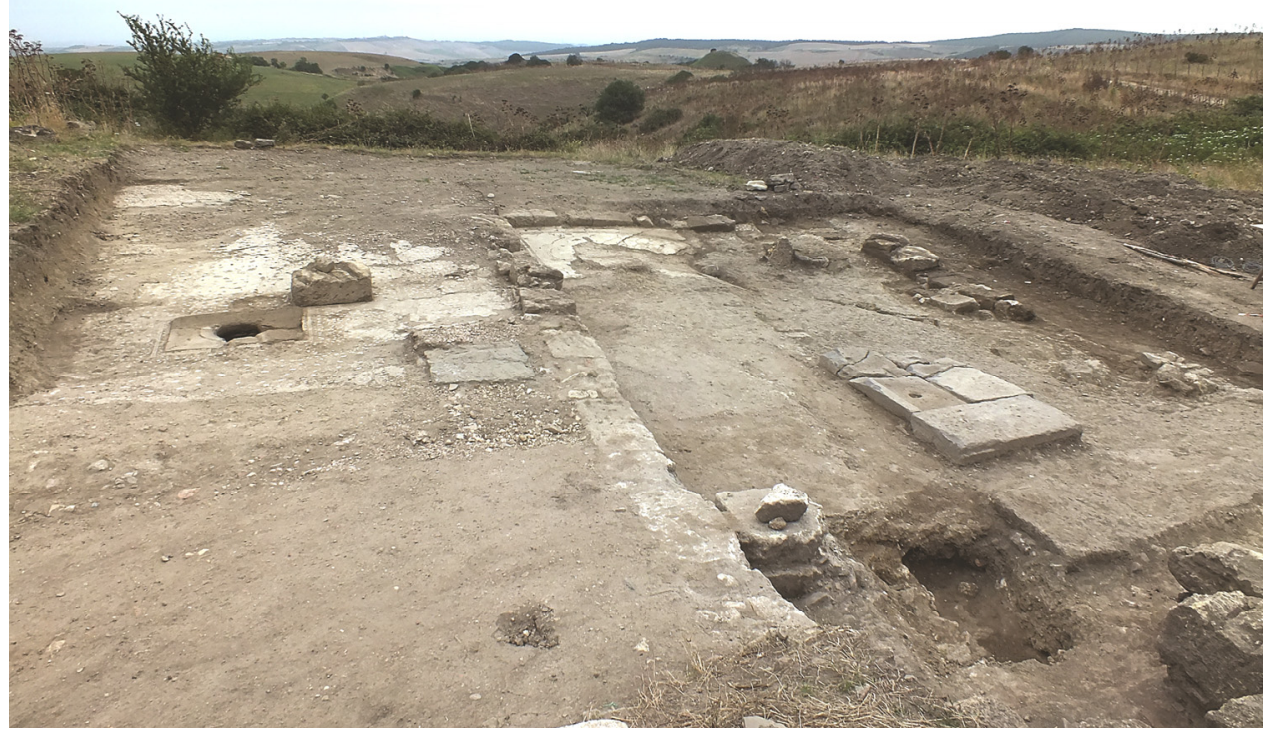

Fig. 9. Tarquinia, loc. "Civita" - Domus of Mithras.

General view of the excavation area in the North direction (photo by M. Benedetti)

The Eastern wall is "a scacchiera" (chessboard-shaped), i.e., made with big macco stone blocks alternating with square stones of another kind.

On the Southern wall a threshold on cocciopesto (beaten pieces of ceramics mixed with mortar or lime) was decorated with crustae on limestone and abutted a big foundation block. This door allowed the passage from room A to room $\mathrm{H}$, which lay on the same level. Here, the most important structure is the circular mouth of a cistern, made with a nenfro stone monolith surrounded by a double line of black and alternating white mosaic pieces, has been laid onto a cocciopesto floor.

Near the perimetral walls of the room, the floor is an opus signinum with crustae on bright limestone surrounding a central "carpet" of opus signinum with polychrome crustae.

This kind of floor can be dated to the late Hellenistic Age, and, more precisely, to the second half of the 2nd century BCE, thanks to comparisons with floors from the Roman villa at Tor Vergata, Rome, ${ }^{5}$ and from late Republican Ostia. ${ }^{6}$ It pertains

\footnotetext{
${ }^{5}$ DE FrANCESCHINI, M.: Ville dell'agro romano. Roma 2005, 206.

${ }^{6}$ Pensabene, P. - LAZZARINI, L.: Ostiensium marmorum decus et decor. Studi architettonici, decorativi e archeometrici. Roma 2007, 267.
} 
to the typology labeled "cementizi a base fittile con inserti marmorei" by Grandi and Guidobaldi. $^{7}$

The circular mouth of the cistern (fig. 10) is $40 \mathrm{~cm}$ large and ca $80 \mathrm{~cm}$ thick; the underground reservoir is ca $2 \mathrm{~m}$ large and ca $5 \mathrm{~m}$ deep from the mouth. It still preserves water $2 \mathrm{~m}$ deep. A video-camera was sent to investigate it, but only collapsed materials were discovered there (fig. 11). The cistern was, and still is, fed in different ways at the same time, and because of this it has been impossible to dry it completely with a pump. This feature suggests that this cistern was made in the framework of the hydraulic system which served all the plateau, as we know thanks to the modern bibliography. ${ }^{8}$

Over the mouth of the cistern a large fragment of a white marble trapeza (a table) has been found, placed upside down in order to fit better the mouth. The marble slab has a square relief which was used to fix the supporting pillar.

It is also worth noting a parallel pipe lying close to the N-E part of the cistern's mouth, which is made of nenfro and macco stone, and of broken, re-used tiles in order to build a solid structure in connection with the cistern. It could have been used as the base of the trapeza (fig. 12) after the marble pillar had been damaged. A marble table close to the water supply also seems to make sense, because a Mithraeum was located nearby, and it required water for its rituals.

The final phase of the room is documented by a fragmentary African amphora, re-used to cover a late-antique burial of an infant (enchytrismos), whose osteological remains are few. This tomb was leaning on the stone base close to the cistern.

\section{ROOM B}

It is difficult to establish the function of the different rooms, because the digging has been limited in time and space, but it is possible to hypothesize that room B has a religious function because the marble dog has been discovered here. The dimensions of the room are $10.50 \mathrm{~m}$ in length and $5.50 \mathrm{~m}$ in width, and it is limited by perimetral walls on the N, E and W sides, whereas the Southern side is still covered by square stone blocks of a collapse. In this part of the room, the Mithraic dog was unearthed, close to the previously clandestine excavation.

The Western wall is preserved with only one row of blocks and is made as an "opera a scacchiera" with square macco blocks. The Northern wall is also similarly preserved: its blocks are bound with mortar, and it is interrupted by a cocciopesto threshold decorated with bright limestone crustae, and was used to pass from room B to room D. The Eastern wall is badly preserved and it, too, is made as an "opera a scacchiera".

${ }^{7}$ GRANDI, M. - GUIDOBALDI, F.: Proposta di classificazione dei cementizi e mosaici omogenei ed eterogenei. In ANGElELli, C. (a cura di): Atti dell'XI Colloquio dell'Associazione Italiana per lo studio e la conservazione del mosaico. Ancona 16-19 Febbraio 2005. Tivoli (Roma) 2006, 31-38.

${ }^{8}$ Bonghi Jovino, M.: Tarquinia etrusca. Tarconte e il primato della città. Roma 2008, 13-15. Padovan, G.: Civita di Tarquinia: indagini speleologiche. Catalogazione e studio delle cavità artificiali rinvenute presso il Pian di Civita e il Pian della Regina [BAR 1039]. Oxford 2002. 


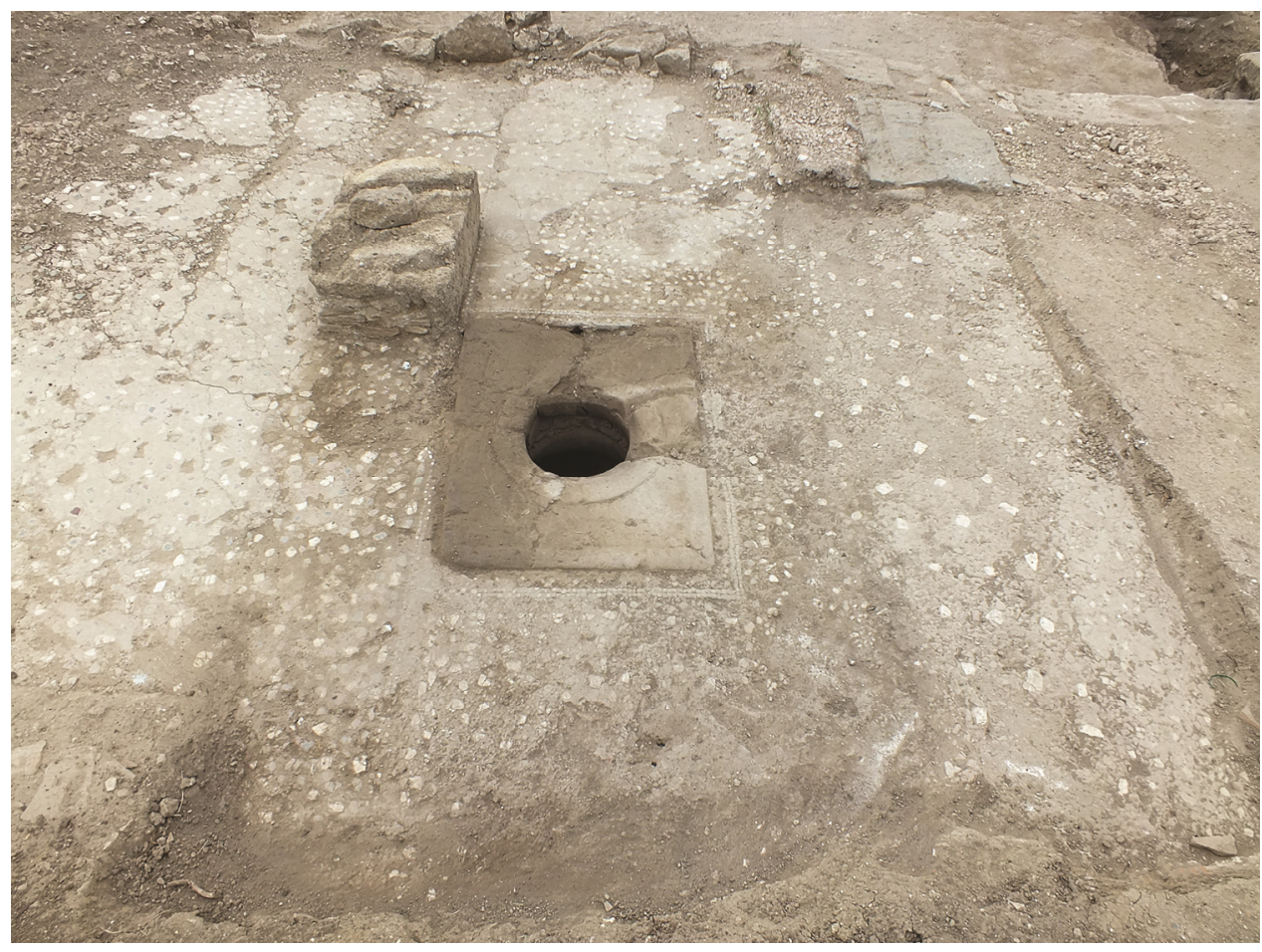

Fig. 10. Tarquinia, loc. "Civita" - Domus of Mithras, room A, cistern opening (photo by M. Benedetti)

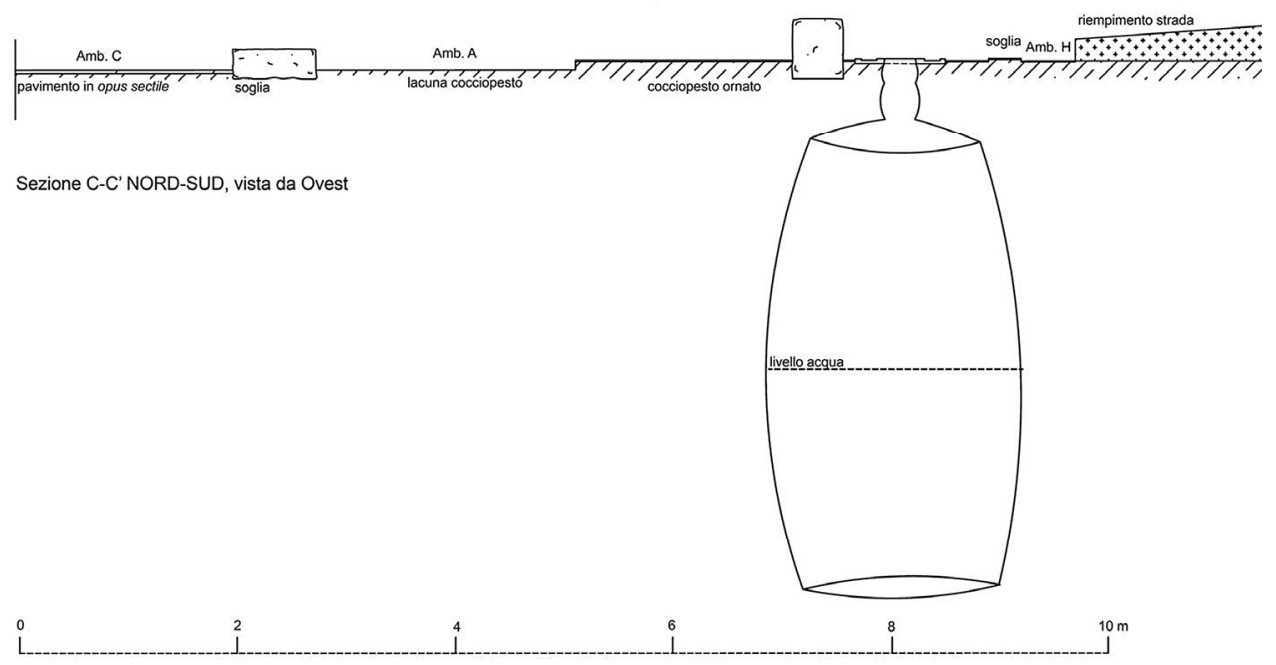

Fig. 11. Tarquinia, loc. "Civita" - Domus of Mithras, room A, cistern section (drawn by the archaeological firm Legni e Segni della Memoria) 


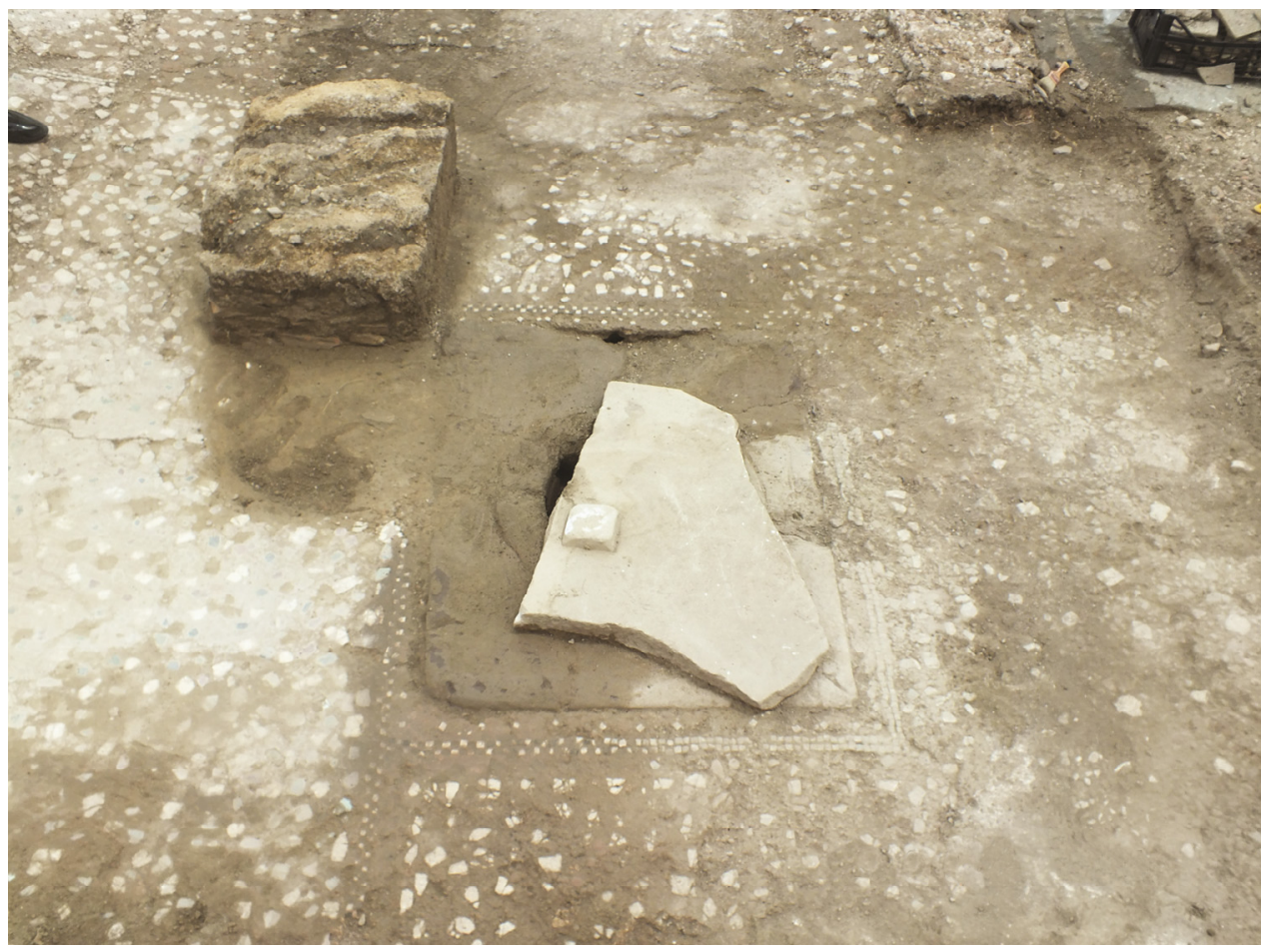

Fig. 12. Tarquinia, loc. "Civita" - Domus of Mithras, room A, closing of the cistern opening (photo by M. Benedetti)

The floor shows missing parts and collapses, especially in its North-Eastern side, due to ploughing and to the collapse of another cistern, which has not been investigated, but has a mouth covered by a cylindrical nenfro stone wellhead, which had been broken and displaced by modern agricultural activities. An adduction channel has been discovered close to the mouth of the cistern.

On the Western side, remains of the original floor have been brought to light, close to the N-W corner, where a simple white and black mosaic can be seen, which can be dated to the 2 nd century CE and whose mosaic square tiles have a measure of ca. $1 \mathrm{~cm}$. The orientation of these tiles deviates from the line of the perimetric walls. The mosaic has a white central floor framed by two black lines alternating with white lines. There is no emblema at the center. But this mosaic did not cover all of room B, because a preparation for another, different floor along the Western side is still visible. This floor was made of square terracotta tiles, which are poorly preserved close to the collapsed blocks on the Southern side. Therefore two different floors co-existed, between which the mosaic was the more ancient one.

At the center of the room a rectangular base (fig. 13) can be seen, $2.16 \mathrm{~m}$ long and $1.36 \mathrm{~m}$ wide, which is made with three big nenfro slabs, that were re-used manholes. The two manholes placed along the longer side of the base are fragmentary: 


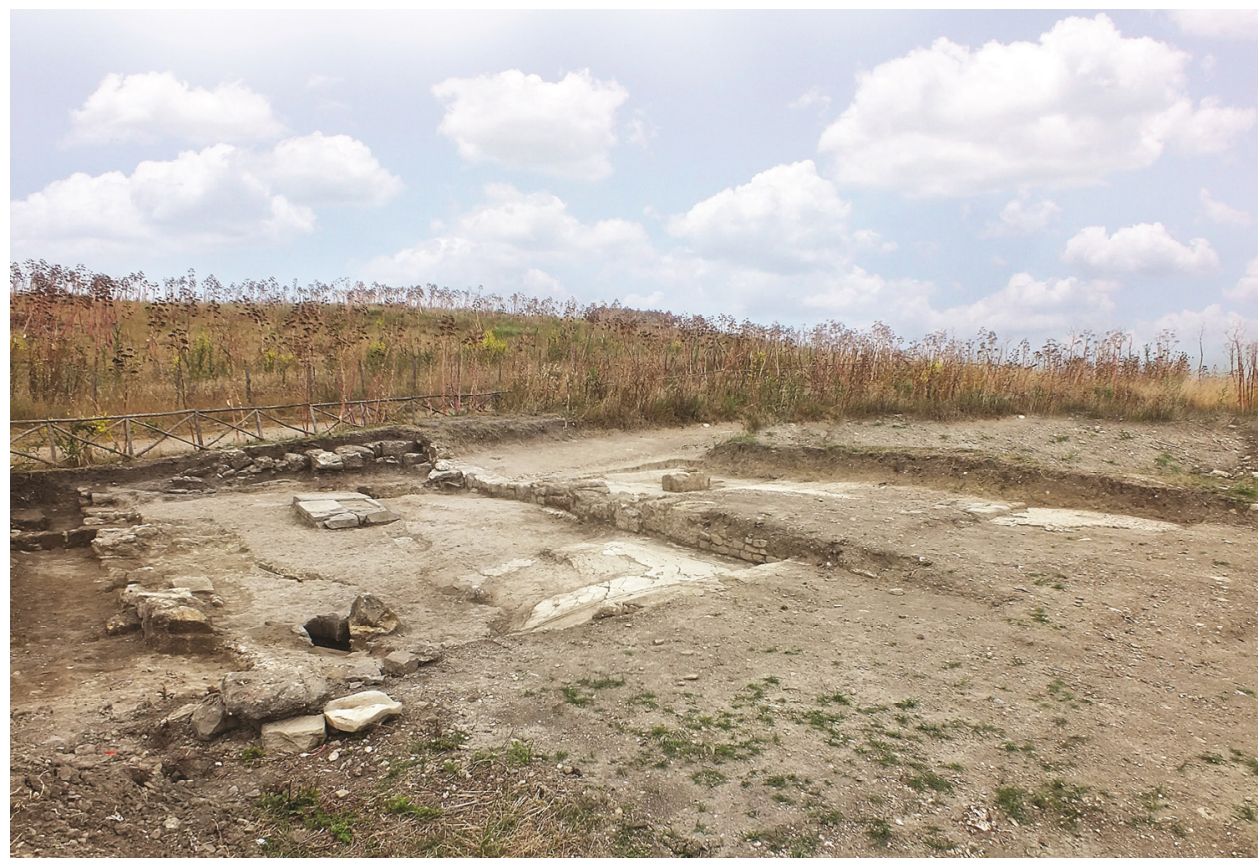

Fig. 13. Tarquinia, loc. "Civita" - Domus of Mithras, general view in the South direction (photo by M. Benedetti)

that in the Western part has a hole (ca. $9 \mathrm{~cm} \mathrm{ø)} \mathrm{and} \mathrm{has} \mathrm{no} \mathrm{indentation} \mathrm{on} \mathrm{the} \mathrm{edge}$ but, instead, a rectangular, lowered zone in the Northern part of the base.

These elements are gathered without mortar, but simply laid on an adjusted area of the floor and put together to create this prominent structure, placed almost at the center of the room, in front of the short wall, from where the statue came.

Between the base and the cistern a small channel can be seen, which is made with terracotta tiles covered by stone slabs and is oblique with respect to the orientation of the room.

Close to the collapsed blocks of the back wall, the Mithraic dog has been found, lying in a secondary emplacement, which dovetails with the fore-knee of the sculptural group discovered by the Carabinieri. This fact proves that the Mithraic statue came from the Tarquinian plateau.

The sculpture was discovered upside down, and this fact suggests a probable violent destruction of this Mithraeum, like that of Vulci, which was destroyed following the Theodosian decree from Thessalonica (380 CE), when Christianity had been declared the State religion, and the further decrees of Theodosius in 391 and $392 \mathrm{CE}$, when the end of paganism and the triumph of Christianity was enacted, due to the prohibition of worshipping statues and making sacrifices to pagan gods. 


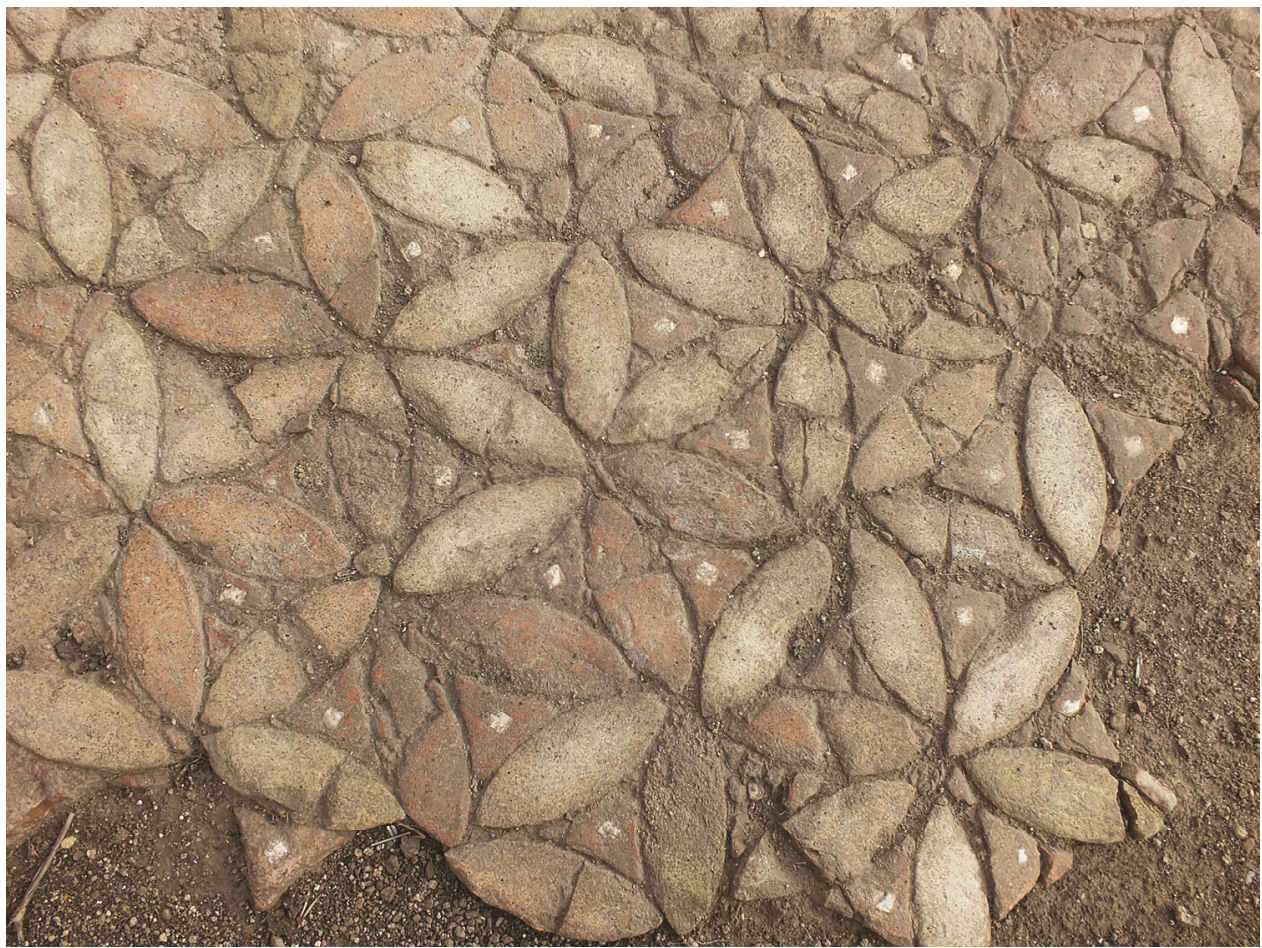

Fig. 14. Tarquinia, loc. "Civita" - Domus of Mithras, room C, detail of the floor with terracotta inlays (photo by M. Benedetti)

\section{ROOM C}

This room has been dug only partially. It is limited on the Southern side by a wall on macco square blocks, whose first row is the only preserved one, along with a threshold leading to room A. Its hollow for a pivot and its indent for the door are still visible. Its floor is noteworthy (fig. 14), for it is made of a rare example of inlaid terracotta elements, made with moulds, in order to compose a regular series of both crossing and abutting circles which frame 6 petaled "flowers" alternating with triangles filled with pieces of white limestone, a feature which creates a color contrast within the floor. The recurring circles have a diameter of $29.6 \mathrm{~cm}$, i.e., a Roman foot.

A good comparison to this floor is the terracotta floor from the villa of Publius Anilius in the Tuscan Maremma, ${ }^{9}$ wherein the decorative pattern is more simple, i.e., a 4-petaled "flower" alternating with a quadrangular inlay consisting of concave quadrangular terracotta pieces and a central piece. This floor can be dated between

${ }^{9}$ Del Chiaro, M. A.: The Villa of Publius Anilius. A Roman Villa in the Maremma, Tuscany. In AoyAgi, M. - SteIngRABer, S. (a cura di): Le ville romane dell'Italia e del Mediterraneo antico. Tokyo 1999, 96-107. 
the end of the Republican period and the beginning of the Imperial Age (1st century BCE - 1st century CE). This decorative pattern is considered by Del Chiaro unique among the terracotta inlaid floors, and therefore the case from Tarquinia, in the abutting Maremma of Lazio, seems to be very interesting.

\title{
CONCLUSIONS
}

Only future archaeological research will be able to establish the features of the plan of this domus, wherein the statue of Mithras has been discovered.

The fact that the cultic place was connected with a complex series of buildings finds a good comparison in the Mithraeum from Vulci, which is abutting the domus del criptoportico. ${ }^{10}$ We can thus suppose that the Mithraeum was reserved for a restricted number of adepts, probably related to the owner of the domus, which can be called "the domus of the Mithras' statue", and also that this cult was private. The origin of this domus traces back to the Hellenistic Age (3rd-2nd centuries BCE), and its end can be dated to Late Antiquity.

Without the discovery of the marble dog, the Mithras group would probably have been labelled a precious piece of a collection but missing a precise archaeological provenance. The high level of this sculpture allow us to assert that Tarquinia was a prominent city in the arts not only during the Etruscan phases, but also during the Imperial Age. Specialists of the University of Verona under the direction of Prof. Attilio Mastrocinque will be entrusted with the forthcoming archaeological research on this site.

\author{
Maria Gabriella Scapaticci \\ Tarquinia National Museum \\ Tarquinia, Italy
}

${ }^{10}$ SGUBini MoretTI, A. M.: Nota su un mitreo scoperto a Vulci. In BiAnCHI, U. (ed.): Mysteria Mithrae. Leiden 1979, 259-276; cf. also SGUBINI MoretTI, A. M.: Il Mitreo. In CARANDINI, A. (a cura di): La romanizzazione dell'Etruria: il territorio di Vulci. Catalogo della mostra (Orbetello 1984). Milano 1985, 73. Cf. SGUBINI MoRetTI, A. M.: Il mitreo di Vulci. Catalogo della mostra (Montalto di Castro 1998). Viterbo 1998. Cf. also CAROSI, S. - PETITTI, P. - CASI, C. (a cura di): Sutri, Vulci e i misteri di Mitra. Culti orientali in Etruria. Catalogo della mostra. Canino, Castello dell'Abbadia, 2016. Cf. in general: Vermaseren, M. J.: Corpus Iscriptionum et Monumentorum Religionis Mithriacae. Dordrecht 1956. On the Mithras cult in Etruria cf. a recent work and a large bibliography by FUSCO, U.: A New Mithraic Relief from Veii (with an Introduction by F. Boitani). Archeologia Classica LXVI, n. s. II 5 (2015) 519546. 
